\title{
Association between Paraoxonase 1 polymorphisms and risk of esophagogastric junction adenocarcinoma: a case-control study involving 2,740 subjects
}

\author{
Weifeng Tang ${ }^{1, *}$, Jianchao Liu, ${ }^{1, *}$, Yafeng Wang ${ }^{2}$, Yanchao Chen ${ }^{3}$, Mingqiang Kang ${ }^{4,5,6}$, \\ Jun Yin ${ }^{1}$, Chao Liu ${ }^{1}$, Jing Lin ${ }^{7}$ and Yu Chen ${ }^{7,8,9}$ \\ ${ }^{1}$ Department of Cardiothoracic Surgery, Affiliated People's Hospital of Jiangsu University, Zhenjiang, Jiangsu Province, China \\ ${ }^{2}$ Department of Cardiology, The People's Hospital of Xishuangbanna Dai Autonomous Prefecture, Jinghong, Yunnan Province, China \\ ${ }^{3}$ Department of Thoracic Surgery, Affiliated Jurong People's Hospital of Jiangsu University, Jurong, Jiangsu Province, China \\ ${ }^{4}$ Department of Thoracic Surgery, Fujian Medical University Union Hospital, Fuzhou, Fujian Province, China \\ ${ }^{5}$ Key Laboratory of Ministry of Education for Gastrointestinal Cancer, Fujian Medical University, Fuzhou, Fujian Province, China \\ ${ }^{6}$ Fujian Key Laboratory of Tumor Microbiology, Fujian Medical University, Fuzhou, Fujian Province, China \\ ${ }^{7}$ Department of Medical Oncology, Fujian Cancer Hospital and Fujian Medical University Cancer Hospital, Fuzhou, Fujian \\ Province, China \\ ${ }^{8}$ Cancer Bio-immunotherapy Center, Fujian Cancer Hospital and Fujian Medical University Cancer Hospital, Fuzhou, Fujian \\ Province, China \\ ${ }^{9}$ Fujian Provincial Key Laboratory of Translational Cancer Medicine, Fuzhou, Fujian Province, China \\ *These authors contributed equally to this work
}

Correspondence to: Weifeng Tang, email: twf001001@126.com Yu Chen, email: 13859089836@139.com

Keywords: PON1, polymorphism, esophagogastric junction adenocarcinoma

Received: June 11, 2017 Accepted: July 25, $2017 \quad$ Published: August 10, 2017

Copyright: Tang et al. This is an open-access article distributed under the terms of the Creative Commons Attribution License 3.0 (CC BY 3.0 ), which permits unrestricted use, distribution, and reproduction in any medium, provided the original author and source are credited.

\section{ABSTRACT}

Esophagogastric junction adenocarcinoma (EGJA) is a serious public health problem with high mortality in China. In this study, we assessed the association between Paraoxonase 1 (PON-1) rs662 C>T, rs854560 A >T polymorphisms and EGJA risk. This case-control study enrolled 2,740 participants of Asians origin from the Eastern Chinese Han populations. SNPscanTM genotyping assay was harnessed to determine the genotyping of PON1 polymorphisms. The PON-1 rs854560 A>T and rs662 C>T genotypes distribution accorded with Hardy-Weinberg equilibrium. We found that there was no difference in the frequency of PON-1 rs662 C>T, rs854560 A $>T$ genotypes between the overall EGJA cases and controls. In the subgroup analyses, the results indicated that PON-1 rs662 C $>$ T polymorphism might be associated with a significantly decreased risk of EGJA in ever smoking group (TT vs. CC/CT: adjusted $\mathrm{OR}=0.58,95 \% \mathrm{CI} 0.35-0.95, P=0.029)$. In conclusion, our study highlights $P O N-1$ rs662 C>T polymorphism may decrease the risk of EGJA, which interacts with the tobacco using. In the future, a fine-mapping case-control study with detailed geneenvironmental data is needed to further assess these potential relationship.

\section{INTRODUCTION}

Esophagogastric junction adenocarcinoma (EGJA) is a common malignancy in North America, Europe and Eastern Asian and is considered that it is different from distal GC [1-3]. In the United States, the data of cancer registry program showed the incidence of EGJA increased 2.5-fold from 1973-1992, and it was stable in the last two decades with 2 per 100,000 morbidity [4]. In Caucasians, the 5 -year relative survival rate was $16-17 \%[4,5]$. It is 
also reported that EGJA is a serious public health problem with high mortality in China. Liu et al. reported that the incidence of EGJA was 34.1\% in all gastric and esophageal adenocarcinomas patients [6]. And 5-year survival rate of EGJA was 29-35.5\% [7, 8]. The pathological process of EGJA is very complex. The etiology of EGJA is unclear. It is believed that food preserved by salting, chronic gastroesophageal reflux disease, smoking, obesity and etc. may contribute to the development of EGJA. Nowadays, accumulating evidences highlighted that individual's genetic background could play a vital role in the carcinogenesis of EGJA. Single nucleotide polymorphisms (SNPs), which could alter the activity of some detoxifying carcinogenic substances, may conduce to the development of EGJA.

Chronic inflammation may influence the susceptibility of malignancy. The potential molecular mechanisms underlying the relationship have been studied and it is identified that a number of inflammation-related cells gathers and secretes some chemical mediators, in particular reactive oxygen species (ROS) [9]. ROS levels within cells and inflammatory tissues are regulated by many free-radical scavenging systems. The excessive ROS damage intracellular macromolecules, including proteins and nucleic acids. Paraoxonase 1 (PON1) gene maps to the long arm of chromosome 7. PON1, an antioxidant enzyme, keeps the balance of antioxidant-oxidant [10-13]. Enzyme Commission of the International Union of Biochemistry and Molecular Biology classifies PON1 as an aryldialkylphosphatase (EC 3.1.8.1) [14]. PON1, a glycoprotein, is a molecular mass of $43 \mathrm{KDa}$. Oxidative stress have been found to be correlated with an increased susceptibility of many malignancies [9]. In vivo, body possesses several free-radical scavenging systems including paraoxonase. PON1 prevents the oxidation of LDL and cell membrane, and therefore it is thought to be atheroprotective. Furthermore, PON1 was found to play an important role in the scavenging of carcinogenic lipidsoluble radicals [15]. In addition, PON1 is versatile and it may contribute to innate immunity, putative new roles in malignancy and the promotion of healthy aging [16]. It was reported that expression or activity of PON1 decreased in lung cancer, multiple myeloma and papillary thyroid cancer [17-19]. Therefore, it is reasonable to believe that the decreased activity of PON1 may be associate with the development of cancer.

PON1 rs662 $\mathrm{C}>\mathrm{T}$ and rs854560 $\mathrm{A}>\mathrm{T}$, two functional SNPs, were identified to be associated with the risk of multiple cancers [20-22]. However, most of the epidemiologic and molecular studies focused on the relationship of $P O N 1$ polymorphisms with the risk of cancer in Caucasians. Thus, the results might remain inconclusive, especially in Asians. Therefore, we conducted this casecontrol study to determine the association between PON1 rs662 C > T, rs854560 A > T polymorphisms and EGJA risk with a large sample size in Eastern Chinese Han populations.

\section{RESULTS}

\section{Baseline characteristics}

The relevant demographics and risk factors are summarized by case/control status in Table 1. EGJA patients and non-cancer controls were similar in terms of age and sex distributions. There were more smokers and drinkers among EGJA patients than among controls. The minor allele frequency (MAF) of PON-1 rs854560 $\mathrm{A}>\mathrm{T}$ and rs662 $\mathrm{C}>\mathrm{T}$ polymorphisms in controls was similar to its data in the database (Table 2). In controls, as demonstrated in Table 2, the PON-1 rs854560 A $>$ T and rs662 C $>$ T genotypes distribution accorded with HardyWeinberg equilibrium (HWE).

\section{Association of $P O N-1$ rs662 $\mathrm{C}>\mathrm{T}$ and $\mathrm{rs854560}$ A $>$ T polymorphisms with EGJA}

The $P O N-1$ rs854560 A $>$ T and rs662 C $>$ T genotypes are summarized in Table 3 . The frequencies of $P O N-1$ rs $854560 \mathrm{AA}, \mathrm{AT}$, and TT genotypes were $93.28 \%, 6.63 \%$ and $0.10 \%$ in EGJA group and $93.97 \%, 5.91 \%$, and $0.12 \%$ in controls, respectively. When the frequency of $P O N-1$ rs854560 AA genotype was used as reference, there was no difference in the frequency of $P O N-1$ rs854560 AT genotype between the EGJA group and the controls (crude OR $=1.11$, 95\% CI: $0.81-1.52, P=0.533)$. When the frequency of $P O N-1$ rs854560 AA genotype was used as reference, we found no difference in the frequency of $P O N-1$ rs854560 TT genotype between EGJA group and the controls (crude OR $=0.79,95 \%$ CI: $0.07-8.76, P=0.850)$. In addition, when the frequency of $P O N-1$ rs 854560 AA genotype was used as reference, there was no difference in the frequency of $P O N$ 1 rs854560 AT/TT genotypes between EGJA group and the controls (crude OR $=1.12,95 \% \mathrm{CI}$ : $0.82-1.54, P=0.471$ ). When the frequency of $P O N-1$ rs 854560 AA/AT genotypes were used as reference, we found there was no difference in the frequency of $P O N-1$ rs854560 TT genotype between EGJA group and the controls (crude OR $=0.80,95 \% \mathrm{CI}$ : 0.07-8.88, $P=0.859$ ). Adjustment for age, sex, smoking and drinking, the similar results were also found (AT vs. AA: adjusted OR, $1.12 ; 95 \%$ CI, $0.81-1.54 ; P=0.488$; TT vs. AA: adjusted OR, 0.90; 95\% CI, 0.08-9.98; $P=0.933$; TT/AT vs. AA: adjusted OR, 1.14; 95\% CI, 0.83-1.56; $P$ $=0.417$; TT vs. AA/AT: adjusted OR, 0.92; 95\% CI, 0.0810.16; $P=0.945$; Table 4).

The frequencies of $P O N-1$ rs $662 \mathrm{CC}, \mathrm{CT}$, and TT genotypes were $39.19 \%, 48.13 \%$ and $12.68 \%$ in EGJA group and $41.28 \%, 46.36 \%$, and $12.37 \%$ in controls, respectively. When the frequency of rs662 CC genotype was used as reference, there was no difference in the frequency of $P O N-1$ rs662 CT genotype between the EGJA group and the controls (crude $\mathrm{OR}=1.04,95 \% \mathrm{CI}$ : $0.88-1.23, P=0.624)$. When the frequency of $P O N-1$ rs662 CC genotype was used as reference, we found there 
Table 1: Distribution of selected demographic variables and risk factors

\begin{tabular}{|c|c|c|c|c|c|}
\hline \multirow{2}{*}{ Variable } & \multicolumn{2}{|c|}{ Overall Cases $(n=1,063)$} & \multicolumn{2}{|c|}{ Overall Controls $(n=1,677)$} & \multirow{2}{*}{$P^{a}$} \\
\hline & $n$ & $\%$ & $n$ & $\%$ & \\
\hline Age (years) & \multicolumn{2}{|c|}{$64.19( \pm 8.63)$} & \multicolumn{2}{|c|}{$63.91( \pm 10.22)$} & 0.451 \\
\hline Age (years) & & & & & 0.165 \\
\hline$<64$ & 494 & 46.47 & 825 & 49.19 & \\
\hline$\geq 64$ & 569 & 53.53 & 852 & 50.81 & \\
\hline Sex & & & & & 0.909 \\
\hline Female & 304 & 28.60 & 483 & 28.80 & \\
\hline Male & 759 & 71.40 & 1194 & 71.20 & \\
\hline Smoking status & & & & & $<0.001$ \\
\hline Never & 773 & 72.72 & 1323 & 78.89 & \\
\hline Ever & 290 & 27.28 & 354 & 21.11 & \\
\hline Alcohol use & & & & & $<0.001$ \\
\hline Never & 908 & 85.42 & 1507 & 89.86 & \\
\hline Ever & 155 & 14.58 & 170 & 10.14 & \\
\hline
\end{tabular}

${ }^{\text {a }}$ Two-sided $\chi^{2}$ test and Student $t$ test.

Table 2: Primary information for PON1 polymorphisms (rs854560 A $>$ T and rs662 C $>$ T)

\begin{tabular}{|c|c|c|}
\hline Genotyped polymorphisms & $\mathrm{rs} 854560 \mathrm{~A}>\mathrm{T}$ & rs662 C $>T$ \\
\hline Chr & 7 & 7 \\
\hline NCBI Build 38 & 95316772 & 95308134 \\
\hline Function $^{\mathrm{a}}$ & missense (dbSNP) & missense (dbSNP) \\
\hline Minor allele frequency a for Chinese in database ${ }^{a}$ & 0.03 & 0.43 \\
\hline Minor allele frequency in our controls $(n=1,677)$ & 0.03 & 0.36 \\
\hline$P$ value for $\mathrm{HWE}^{\mathrm{b}}$ test in our controls & 0.733 & 0.632 \\
\hline$\%$ Genotyping value & 99.09 & 99.09 \\
\hline
\end{tabular}

${ }^{a}$ http://gvs.gs.washington.edu/GVS147/.

${ }^{b}$ HWE: Hardy-Weinberg equilibrium.

was no difference in the frequency of $P O N-1$ rs662 TT genotype between EGJA group and the controls (crude $\mathrm{OR}=1.03,95 \% \mathrm{CI}: 0.80-1.32, P=0.821)$. In addition, when the frequency of $P O N-1$ rs662 CC genotype was used as reference, there was no difference in the frequency of $P O N-1$ rs662 CT/TT genotypes between EGJA group and the controls (crude $\mathrm{OR}=1.09,95 \% \mathrm{CI}$ : $0.93-1.28$, $P=0.282$ ). When the frequency of $P O N-1 \mathrm{rs} 662 \mathrm{CC} / \mathrm{CT}$ genotypes were used as reference, no difference was found in the frequency of $P O N-1$ rs662 TT genotype between EGJA group and the controls (crude $\mathrm{OR}=1.03,95 \% \mathrm{CI}$ : $0.82-1.30, P=0.809$ ). Adjustment for age, sex, smoking and drinking, the similar results were also found (CT vs. CC: adjusted OR, 1.04; 95\% CI, 0.88-1.23; $P=0.651$; TT vs. CC: adjusted OR, $1.01 ; 95 \%$ CI, $0.79-1.30 ; P=0.929$; TT/CT vs. CC: adjusted OR, 1.09; 95\% CI, 0.93-1.27; $P=0.315$; TT vs. CC/CT: adjusted OR, $1.01 ; 95 \% \mathrm{CI}$, $0.80-1.28 ; P=0.915$; Table 4).

\section{Association of $P O N-1$ rs662 $\mathrm{C}>\mathrm{T}$ and $\mathrm{rs854560}$ $A>T$ polymorphisms with EGJA in Different Stratification Groups}

The $P O N-1$ rs $854560 \mathrm{~A}>\mathrm{T}$ genotype frequencies in the different stratified analyses are summarized in Table 5. We found that $P O N-1$ rs $854560 \mathrm{~A}>\mathrm{T}$ polymorphism was not associated with the risk of EGJA in any subgroup (Table 5).

The $P O N-1$ rs662 C>T genotype frequencies in the different stratified analyses are summarized in Table 6. After adjustment by logistic regression analysis, the results indicated that $P O N-1$ rs $662 \mathrm{C}>\mathrm{T}$ polymorphism might be associated with a significantly decreased risk of EGJA in ever smoking group [TT vs. CC/CT: adjusted OR $=0.58,95 \%$ CI $0.35-0.95, P=0.029$ (Table 6)]. In other subgroups, we did not find any association between $P O N-1$ rs662 C $>$ T polymorphism and the risk of EGJA (Table 6). 
Table 3: The frequencies of $P O N 1$ rs854560 A $>$ T and rs662 C $>$ T polymorphisms

\begin{tabular}{|c|c|c|c|c|}
\hline \multirow{2}{*}{ Genotype } & \multicolumn{2}{|c|}{ Overall EGJA case $(n=1,063)$} & \multicolumn{2}{|c|}{ Overall Controls $(n=1,677)$} \\
\hline & $n$ & $\%$ & $n$ & $\%$ \\
\hline \multicolumn{5}{|l|}{ rs $854560 \mathrm{~A}>\mathrm{T}$} \\
\hline AA & 971 & 93.28 & 1573 & 93.97 \\
\hline AT & 69 & 6.63 & 99 & 5.91 \\
\hline TT & 1 & 0.10 & 2 & 0.12 \\
\hline $\mathrm{AT}+\mathrm{TT}$ & 70 & 6.72 & 101 & 6.03 \\
\hline $\mathrm{AA}+\mathrm{AT}$ & 1040 & 99.90 & 1,672 & 99.88 \\
\hline T allele & 71 & 3.41 & 103 & 3.08 \\
\hline \multicolumn{5}{|l|}{ rs662 C>T } \\
\hline $\mathrm{CC}$ & 408 & 39.19 & 691 & 41.28 \\
\hline CT & 501 & 48.13 & 776 & 46.36 \\
\hline $\mathrm{TT}$ & 132 & 12.68 & 207 & 12.37 \\
\hline $\mathrm{TT}+\mathrm{CT}$ & 633 & 60.81 & 983 & 58.72 \\
\hline $\mathrm{CT}+\mathrm{CC}$ & 909 & 87.32 & 1,467 & 87.63 \\
\hline $\mathrm{T}$ allele & 765 & 36.70 & 1,190 & 35.54 \\
\hline
\end{tabular}

EGJA patients and controls.

Table 4: Analyses of the association between $P O N 1$ rs854560 A $>$ T, rs662 C $>$ T polymorphisms and the risk of EGJA

\begin{tabular}{lllll}
\hline \multirow{2}{*}{ Genotype } & \multicolumn{3}{c}{ Overall (1,063 cases vs. 1,677 controls) } \\
\cline { 2 - 5 } & Crude OR (95\%CI) & $\boldsymbol{P}$ & Adjusted ORa (95\%CI) & $\boldsymbol{P}$ \\
\hline rs854560 A>T & & & & 0.488 \\
additive model & $1.11(0.81-1.52)$ & 0.533 & $1.12(0.81-1.54)$ & 0.933 \\
homozygote model & $0.79(0.07-8.76)$ & 0.850 & $0.90(0.08-9.98)$ & 0.417 \\
Dominant model & $1.12(0.82-1.54)$ & 0.471 & $1.14(0.83-1.56)$ & 0.945 \\
Recessive model & $0.80(0.07-8.88)$ & 0.859 & $0.92(0.08-10.16)$ & 0.651 \\
rs662 C>T & & & & 0.929 \\
additive model & $1.04(0.88-1.23)$ & 0.624 & $1.04(0.88-1.23)$ & 0.315 \\
homozygote model & $1.03(0.80-1.32)$ & 0.821 & $1.01(0.79-1.30)$ & 0.915 \\
Dominant model & $1.09(0.93-1.28)$ & 0.282 & $1.09(0.93-1.27)$ & $1.01(0.80-1.28)$ \\
Recessive model & $1.03(0.82-1.30)$ & 0.809 & & \\
\hline
\end{tabular}

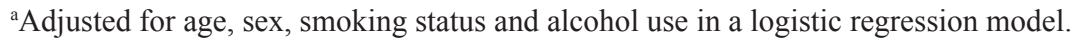

\section{DISCUSSION}

EGJA is thought to be an independent malignancy entirety of upper digestive tract tumors [23]. It is reported that the incidence of EGJA is increasing worldwide $[1-3,24]$. A number of previous studies indicated that dietary habits, lifestyle (e.g. smoking and drinking et al.), oxidative and carbonyl stresses, and estrogens might play important roles in carcinogenesis [25-30]. In vivo, there are many antioxidant enzyme which may prevent genotoxic damage. PON1, an antioxidant enzyme, may play a vital role in keeping the balance of antioxidantoxidant balance $[11,31]$. Several studies reported that expression or activity of PON1 decreased in several cancers [17-19]. Considering the potential role of PON1 in carcinogenesis, we selected two most common PON1 polymorphisms (rs662 $\mathrm{C}>\mathrm{T}$ and rs854560 A>T) and assessed their susceptibility to EGJA. In this study, we identified that PON1 rs662 $\mathrm{C}>\mathrm{T}$ polymorphism was associated with the decrease the risk of EGJA in ever smoking subgroup.

It was found that expression or activity of PON1 was lower in cancer patients than controls [17-19]. Delimaris et al. reported that oxidative stress might contribute to pathogenesis of cancer involving the proliferation and malignancy conversion [32]. Previous 
Table 5: Stratified analyses between $P O N-1$ rs854560 A $>$ T polymorphism and EGJA risk by sex, age, smoking status and alcohol consumption

\begin{tabular}{|c|c|c|c|c|c|c|c|c|}
\hline \multirow{2}{*}{ Variable } & \multicolumn{3}{|c|}{$P O N-1$ rs854560 A $>$ T (case/control) a } & \multicolumn{5}{|c|}{ Adjusted OR b (95\% CI); P } \\
\hline & $\mathbf{A A}$ & $\mathbf{A T}$ & TT & $\mathbf{A A}$ & AT & TT & AT/TT & TT vs. $(\mathrm{AA} / \mathrm{AT})$ \\
\hline \multicolumn{9}{|l|}{ Sex } \\
\hline Male & $696 / 1222$ & $49 / 68$ & $1 / 1$ & 1.00 & $\begin{array}{l}1.17(0.80-1.71) \\
P: 0.422\end{array}$ & $\begin{array}{l}1.84(0.12-29.48) \\
P: 0.667\end{array}$ & $\begin{array}{l}1.20(0.82-1.75) \\
P: 0.347\end{array}$ & $\begin{array}{l}1.86(0.12-29.79) \\
P: 0.661\end{array}$ \\
\hline Female & $275 / 451$ & $20 / 31$ & $0 / 1$ & 1.00 & $\begin{array}{l}0.95(0.53-1.72) \\
P: 0.875\end{array}$ & - & $\begin{array}{l}0.96(0.53-1.72) \\
P: 0.885\end{array}$ & - \\
\hline \multicolumn{9}{|l|}{ Age } \\
\hline$<64$ & $449 / 777$ & $32 / 45$ & $1 / 1$ & 1.00 & $\begin{array}{l}1.19(0.74-1.90) \text {; } \\
P: 0.479\end{array}$ & $\begin{array}{l}2.00(0.12-32.03) \\
P: 0.625\end{array}$ & $\begin{array}{l}1.23(0.77-1.96) ; \\
P: 0.383\end{array}$ & $\begin{array}{l}2.03(0.13-32.61) \\
P: 0.617\end{array}$ \\
\hline$\geq 64$ & $522 / 796$ & $37 / 54$ & $0 / 1$ & 1.00 & $\begin{array}{l}1.03(0.66-1.59) \text {; } \\
P: 0.908\end{array}$ & - & $\begin{array}{l}1.03(0.67-1.59) \\
P: 0.894\end{array}$ & - \\
\hline \multicolumn{9}{|l|}{$\begin{array}{l}\text { Smoking } \\
\text { status }\end{array}$} \\
\hline Never & $700 / 1,239$ & $53 / 80$ & $1 / 2$ & 1.00 & $\begin{array}{l}1.13(0.79-1.62) \text {; } \\
P: 0.501\end{array}$ & $\begin{array}{l}0.89(0.08-9.84) \\
P: 0.923\end{array}$ & $\begin{array}{l}1.16(0.81-1.65) \\
P: 0.429\end{array}$ & $\begin{array}{l}0.90(0.08-10.00) \\
P: 0.934\end{array}$ \\
\hline Ever & $271 / 334$ & $16 / 19$ & $0 / 0$ & 1.00 & $\begin{array}{l}1.04(0.52-2.08) \\
P: 0.919\end{array}$ & - & $\begin{array}{l}1.05(0.52-2.10) \\
P: 0.900\end{array}$ & - \\
\hline \multicolumn{9}{|c|}{$\begin{array}{l}\text { Alcohol } \\
\text { consumption }\end{array}$} \\
\hline Never & $823 / 1414$ & $63 / 89$ & $1 / 2$ & 1.00 & $\begin{array}{l}1.18(0.84-1.64) ; \\
P: 0.342\end{array}$ & $\begin{array}{l}0.89(0.08-9.83) \\
P: 0.923\end{array}$ & $\begin{array}{l}1.20(0.86-1.67) \\
P: 0.285\end{array}$ & $\begin{array}{l}0.90(0.08-9.98) \\
P: 0.932\end{array}$ \\
\hline Ever & $148 / 159$ & $6 / 10$ & $0 / 0$ & 1.00 & $\begin{array}{l}0.58(0.20-1.70) \\
P: 0.320\end{array}$ & - & $\begin{array}{l}0.58(0.20-1.71) \\
P: 0.325\end{array}$ & - \\
\hline
\end{tabular}

a The genotyping was successful in 1063 (97.93\%) EGJA cases, and 1677 (99.82\%) controls for $P O N-1$ rs854560 A $>$ T.

${ }^{\mathrm{b}}$ Adjusted for age, sex, smoking status and alcohol consumption (besides stratified factors accordingly) in a logistic regression model.

studies demonstrated that the variants of the PON1 could affect the activity of PON1 protein. Thus, it was necessary to predict whether PON1 polymorphisms might influence the development of EGJA. In this casecontrol study, we aimed to determine the relationship between $P O N 1$ polymorphisms and EGJA risk. We found that PON1 rs662 T allele might decrease the risk of EGJA in ever smoking subgroup, suggesting that $P O N 1$ rs662 C $>$ T polymorphism might act as a protective factor for EGJA. Kahraman et al. found tobacco exposure increased oxidative stress and decreased paraoxonase-1 [33]. The coding region PON1 rs662 $\mathrm{C}>\mathrm{T}$ polymorphism (R192Q) leads to an amino acid substitution and determines a substrate dependent effect on activity. Eom et al. reported that PON1 rs662 TT/CT carriers had the lower urinary 8-hydroxydeoxyguanosine and thiobarbituric acid reactive substances levels compared with rs662 CC carriers in lung cancer patients and decreased the risk of lung cancer [34]. Recently, the association between the decreased risk of cancer and PON1 rs662 C>T polymorphism was also found in Asians [35]. Our findings were similar to the results of these studies. However, there were only a few casecontrol studies with small sample size conducted in Asians. The evidence might be limited. In the future, more case-control studies focusing on the relationship of PON1 rs662 C $>$ T polymorphism with cancer risk should be performed to confirm these potential associations.
There are some limitations which may be interpreted. Firstly, although the number of the participants was relatively large, when the stratification analyses were carried out for the age, sex, smoking and drinking status, resulting in insufficient capacity which limited the power of this study. Secondly, the enrolled participants were from local hospitals, which might lead to the bias. Thirdly, there were only two missense SNPs in PON1 gene included in this case-control study. In the future, a fine-mapping study should be performed to further determine the potential association between the functional SNPs in PON1 gene and EGJA risk. Fourthly, only the information of drinking and smoking was collected as major risk factor. Other potential risk factors [e.g. gastroesophageal reflux disease, obesity, Helicobacter pylori infection status and dietary behavior (low intake of fruit and veggies, pickled food consumption, and drinking beverages at high temperatures etc.)] were not considered. Fifthly, biomarkers for oxidative stress were not measured in our study. Finally, for lack of raw data from other lifestyles, we did not further assess the relationships for the potential interactions of gene-gene or gene-environment factors.

In conclusion, our study highlights PON1 rs662 $\mathrm{C}>\mathrm{T}$ polymorphism may be correlated with the decreased risk of EGJA which interacted with the tobacco using. In the future, a fine-mapping case-control study are needed to further assess the potential relationship between $P O N 1$ SNPs and EGJA risk. 
Table 6: Stratified analyses between $P O N-1$ rs662 C $>$ T polymorphism and EGJA risk by sex, age, smoking status and alcohol consumption

\begin{tabular}{|c|c|c|c|c|c|c|c|c|}
\hline \multirow{2}{*}{ Variable } & \multicolumn{3}{|c|}{ PON-1 rs662 C $>$ T (case/control) ${ }^{a}$} & \multicolumn{5}{|c|}{ Adjusted OR b $(95 \%$ CI $) ; P$} \\
\hline & $\mathrm{CC}$ & CT & TT & CC & CT & TT & CT/ TT & TT vs. $(\mathrm{CT} / \mathrm{CC})$ \\
\hline \multicolumn{9}{|l|}{ Sex } \\
\hline Male & $285 / 488$ & $370 / 553$ & $91 / 150$ & 1.00 & $\begin{array}{l}1.10(0.90-1.34) \\
P: 0.344\end{array}$ & $\begin{array}{l}0.98(0.73-1.32) \text {; } \\
P: 0.902\end{array}$ & $\begin{array}{l}1.12(0.93-1.35) \\
P: 0.250\end{array}$ & $\begin{array}{l}0.95(0.72-1.25) \\
P: 0.706\end{array}$ \\
\hline Female & $123 / 203$ & $131 / 223$ & $41 / 57$ & 1.00 & $\begin{array}{l}0.90(0.66-1.23) \\
P: 0.504\end{array}$ & $\begin{array}{l}1.08(0.68-1.72) ; \\
P: 0.740\end{array}$ & $\begin{array}{l}1.01(0.75-1.36) \\
P: 0.962\end{array}$ & $\begin{array}{l}1.18(0.76-1.83) ; \\
P: 0.452\end{array}$ \\
\hline \multicolumn{9}{|l|}{ Age } \\
\hline$<64$ & $197 / 340$ & $228 / 383$ & $57 / 100$ & 1.00 & $\begin{array}{l}0.96(0.76-1.23) \\
P: 0.765\end{array}$ & $\begin{array}{l}0.90(0.62-1.31) \\
P: 0.592\end{array}$ & $\begin{array}{l}1.01(0.80-1.27) \\
P: 0.969\end{array}$ & $\begin{array}{l}0.94(0.67-1.34) \\
P: 0.749\end{array}$ \\
\hline$\geq 64$ & $211 / 351$ & $273 / 393$ & $75 / 107$ & 1.00 & $\begin{array}{l}1.11(0.89-1.40) \\
P: 0.363\end{array}$ & $\begin{array}{l}1.11(0.79-1.56) ; \\
P: 0.556\end{array}$ & $\begin{array}{l}1.16(0.93-1.45) \\
P: 0.183\end{array}$ & $\begin{array}{l}1.07(0.78-1.47) \\
P: 0.694\end{array}$ \\
\hline \multicolumn{9}{|c|}{ Smoking status } \\
\hline Never & $301 / 539$ & $350 / 628$ & $103 / 154$ & 1.00 & $\begin{array}{l}0.94(0.78-1.14) \\
P: 0.546\end{array}$ & $\begin{array}{l}1.13(0.85-1.50) \text {; } \\
P: 0.403\end{array}$ & $\begin{array}{l}1.04(0.86-1.25) \\
P: 0.693\end{array}$ & $\begin{array}{l}1.20(0.92-1.57) \\
P: 0.188\end{array}$ \\
\hline Ever & $107 / 152$ & $151 / 148$ & $29 / 53$ & 1.00 & $\begin{array}{l}1.40(0.99-1.96) ; \\
P: 0.054\end{array}$ & $\begin{array}{l}0.69(0.41-1.16) ; \\
P: 0.160\end{array}$ & $\begin{array}{l}1.23(0.89-1.70) \\
P: 0.216\end{array}$ & $\begin{array}{l}0.58(0.35-0.95) \\
\text { P: } 0.029\end{array}$ \\
\hline \multicolumn{9}{|c|}{$\begin{array}{l}\text { Alcohol } \\
\text { consumption }\end{array}$} \\
\hline Never & $354 / 627$ & $422 / 700$ & $111 / 178$ & 1.00 & $\begin{array}{l}1.01(0.85-1.21) \\
P: 0.897\end{array}$ & $\begin{array}{l}1.04(0.80-1.37) \\
P: 0.760\end{array}$ & $\begin{array}{l}1.08(0.91-1.27) ; \\
P: 0.398\end{array}$ & $\begin{array}{l}1.06(0.83-1.37) ; \\
P: 0.634\end{array}$ \\
\hline Ever & $54 / 64$ & $79 / 76$ & $21 / 29$ & 1.00 & $\begin{array}{l}1.21(0.74-1.99) ; \\
P: 0.443\end{array}$ & $\begin{array}{l}0.91(0.45-1.81) \\
P: 0.778\end{array}$ & $\begin{array}{l}1.13(0.70-1.81) ; \\
P: 0.615\end{array}$ & $\begin{array}{l}0.81(0.43-1.53) \\
P: 0.512\end{array}$ \\
\hline
\end{tabular}

a The genotyping was successful in 1063 (97.93\%) EGJA cases, and 1677 (99.82\%) controls for PON-1 rs662 C>T.

${ }^{\mathrm{b}}$ Adjusted for age, sex, smoking status and alcohol consumption (besides stratified factors accordingly) in a logistic regression model.

\section{MATERIALS AND METHODS}

\section{Subjects}

This case-control study enrolled 2,740 participants of Asians origin from the Chinese Han population. Cases $(n=1,063)$ were newly diagnosed EGJA patients at Fujian Medical University Union Hospital and Fujian Medical University Cancer Hospital from January 2014 to May 2016, and at Affiliated People's Hospital of Jiangsu University from January 2008 to November 2016. EGJA patients were included consecutively. Two experienced pathologists confirmed the diagnosis of EGJA for all cases. The major selection criterion for EGJA cases were: (a) all EGJA cases were Siewert II subtype; (b) Patients were Eastern Chinese Han population, and (c) EGJA was confirmed via histopathological examinations. The major exclusion criteria for EGJA cases were: (1) had a history of personal autoimmune disease, (2) EGJA cases who received prior chemoradiotherapy and (3) had a history of another malignancy. At the same time, non-cancer controls were recruited from the Physical Examination Center of these local hospitals. The control subjects had no history of autoimmune disorder or personal malignancy, and were frequency matched to EGJA patients by sex and age. These subjects have been reported in our previous study [36].

Two trained personnels interviewed each participant. The demographic and lifestyle characteristics were obtained by using a questionnaire. Information on smoking, drinking, age and sex was collected for the present study. All participants were informed and signed written consent to allow their blood samples to be genetically tested. Approval was given by the ethical committees of Jiangsu University and Fujian Medical University, in accordance with the Declaration of Helsinki.

\section{DNA extraction and genotyping}

DNA from the participants was extracted from (EDTA)-anticoagulated blood samples with Promega DNA Kit (Promega, Madison, USA). The obtained DNA sample was stored at $-80^{\circ} \mathrm{C}$. Genotyping was carried out by using SNPscan $^{\text {TM }}$ assay (Genesky Biotechologies Inc., Shanghai, China) to determine the genotypes of $P O N-1$ rs 854560 $\mathrm{A}>\mathrm{T}$ and rs662 $\mathrm{C}>\mathrm{T}$ polymorphisms. For quality control, 110 DNA samples randomly selected from 2,740 specimens were reanalyzed. The genotypes of $P O N-1$ rs $854560 \mathrm{~A}>\mathrm{T}$ and rs662 $\mathrm{C}>\mathrm{T}$ polymorphisms were confirmed by another laboratory technicians. As shown in Table 2, the success rate of $P O N-1$ genotyping was both more than $99 \%$.

\section{Statistical analysis}

The HWE in controls was tested by the internetbased $\chi^{2}$ test (http://ihg.gsf.de/cgi-bin/hw/hwa1.pl). The categorical variables (e.g. genotype distributions, age, sex, smoking status, and alcohol consumption) were compared 
by using Chi-square test $\left(\chi^{2}\right)$. The continuous variable was compared by using Student's t-test. To test the hypothesis of relationship of $P O N-1$ genetic polymorphisms with EGJA risk, multivariate logistic regression analyses were used. The SAS 9.4 statistical package (SAS Institute Inc., Cary, NC, USA) was harnessed to calculate the results.

\section{ACKNOWLEDGMENTS}

We appreciate all subjects who participated in this study. We wish to thank Dr. Yan Liu (Genesky Biotechnologies Inc., Shanghai, China) for technical support.

\section{CONFLICTS OF INTEREST} interes.

The authors have no potential financial conflicts of

\section{GRANT SUPPORT}

This study was supported in part by Natural Science Foundation of Universities and Colleges of Jiangsu Province (Grant No. 16KJB310002), Senior Talents Scientific Research Foundation of Jiangsu University (Grant No. 16JDG066), Young and Middleaged Talent Training Project of Health Development Planning Commission in Fujian Province (2016-ZQN25 and 2014-ZQN-JC-11), Medical Innovation Project of Fujian Province (2014-CX-15 and 2014-CX-18), Nursery Garden Project of Fujian Medical University (2015MP020), Science and Technology Project of Fujian Province (2060203), the Natural Science Foundation of Fujian Province (Grant No. 2015J01435, 2017J01259), the Foundation for Yong Scholars of Fujian Provincial Health and Family Planning Commission (Grant No.2016-1-11), the National Natural Science Foundation of China (81000028, 81370001, 81570031, 81300037, 81101889, 81472332, 81341006); the Key Research and Development Program of Jiangsu Province (BE2016714); the Natural Science Foundation of Jiangsu Province (BK2010333, BK2011481); the "333" Elitist Training Program, Jiangsu, China (BRA2013135); the "Six Talent Peaks" Training Program, Jiangsu, China (2014-WSN-078, 2015-WSN117); the "Distinguished Medical Specialist" Program, Jiangsu, China; the "Innovative and Entrepreneurial Elite Team" Program (2016), Jiangsu, China and the Zhenjiang Social Development Program (SH2013039) and the National Clinical Key Specialty Construction Program.

\section{REFERENCES}

1. Jemal A, Center MM, DeSantis C, Ward EM. Global patterns of cancer incidence and mortality rates and trends. Cancer Epidem Biomar. 2010; 19:1893-1907.
2. Blaser MJ, Saito D. Trends in reported adenocarcinomas of the oesophagus and gastric cardia in Japan. Eur J Gastroen Hepat. 2002; 14:107-113.

3. Zhou Y, Zhang Z, Zhang Z, Wu J, Ren D, Yan X, Wang Q, Wang Y, Wang H, Zhang J, Zhu X, Yang Y, Luo C, et al. A rising trend of gastric cardia cancer in Gansu Province of China. Cancer Lett. 2008; 269:18-25.

4. Buas MF, Vaughan TL. Epidemiology and risk factors for gastroesophageal junction tumors: understanding the rising incidence of this disease. Semin Radiat Oncol. 2013; 23:3-9.

5. Akhondi-Meybodi M, Ghane M, Akhondi-Meybodi S, Dashti G. Five-year Survival Rate for Gastric Cancer in Yazd Province, Central Iran, from 2001 to 2008. Middle East J Dig Dis. 2017; 9:39-48.

6. Liu K, Yang K, Zhang W, Chen X, Chen X, Zhang B, Chen Z, Chen J, Zhao Y, Zhou Z, Chen L, Hu J. Changes of Esophagogastric Junctional Adenocarcinoma and Gastroesophageal Reflux Disease Among Surgical Patients During 1988-2012: A Single-institution, High-volume Experience in China. Ann Surg. 2016; 263:88-95.

7. Zheng L, Wu C, Xi P, Zhu M, Zhang L, Chen S, Li X, Gu J, Zheng Y. The survival and the long-term trends of patients with gastric cancer in Shanghai, China. BMC Cancer. 2014; $14: 300$.

8. Zheng B, Chen YB, Hu Y, Wang JY, Zhou ZW, Fu JH. Trend analysis for clinical characteristics and prognosis of adenocarcinoma of cardia. [Article in Chinese]. Chinese Chin J Cancer. 2010; 29:94-97.

9. Farinati F, Piciocchi M, Lavezzo E, Bortolami M, Cardin R. Oxidative stress and inducible nitric oxide synthase induction in carcinogenesis. Dig Dis. 2010; 28:579-584.

10. Yu BP. Cellular defenses against damage from reactive oxygen species. Physiol Rev. 1994; 74:139-162.

11. Karaman E, Uzun H, Papila I, Balci H, Ozdilek A, Genc H, Yanardag H, Papila C. Serum paraoxonase activity and oxidative DNA damage in patients with laryngeal squamous cell carcinoma. J Craniofac Surg. 2010; 21:1745-1749.

12. Ivanisevic J, Kotur-Stevuljevic J, Stefanovic A, Miljkovic M, Jelic-Ivanovic Z, Pejovic B, Peco-Antic A. Association of paraoxonase 1 and oxidative stress with acute kidney injury in premature asphyxiated neonates. Chem-Biol Interact. 2017; 272:47-52.

13. Assis RP, Arcaro CA, Gutierres VO, Oliveira JO, Costa PI, Baviera AM, Brunetti IL. Combined Effects of Curcumin and Lycopene or Bixin in Yoghurt on Inhibition of LDL Oxidation and Increases in HDL and Paraoxonase Levels in Streptozotocin-Diabetic Rats. Int J Mol Sci. 2017; 18.

14. Mackness B, Durrington PN, Mackness MI. Human serum paraoxonase. Gen Pharmacol. 1998; 31:329-336.

15. Shih DM, Gu L, Xia YR, Navab M, Li WF, Hama S, Castellani LW, Furlong CE, Costa LG, Fogelman AM, Lusis AJ. Mice lacking serum paraoxonase are susceptible to organophosphate toxicity and atherosclerosis. Nature. 1998; 394:284-287. 
16. Mackness M, Mackness B. Human paraoxonase-1 (PON1): Gene structure and expression, promiscuous activities and multiple physiological roles. Gene. 2015; 567:12-21.

17. Elkiran ET, Mar N, Aygen B, Gursu F, Karaoglu A, Koca S. Serum paraoxonase and arylesterase activities in patients with lung cancer in a Turkish population. BMC Cancer. 2007; 7:48.

18. Faridvand Y, Oskuyi AE, Khadem-Ansari MH. Serum 8 -isoprostane levels and paraoxonase 1 activity in patients with stage I multiple myeloma. Redox Rep. 2016; 21:204 208.

19. Korkmaz H, Tabur S, Ozkaya M, Aksoy N, Yildiz H, Akarsu E. Paraoxonase and arylesterase activities in patients with papillary thyroid cancer. Scand J Clin Lab Inv. 2015; 75:259-264.

20. Chen L, Lu W, Fang L, Xiong H, Wu X, Zhang M, Wu S, $\mathrm{Yu}$ D. Association between L55M polymorphism in Paraoxonase 1 and cancer risk: a meta-analysis based on 21 studies. Oncotargets Ther. 2016; 9:1151-1158.

21. Zhang M, Xiong H, Fang L, Lu W, Wu X, Huang ZS, Wang YQ, Cai ZM, Wu S. Paraoxonase 1 (PON1) Q192R Gene Polymorphism and Cancer Risk: A Meta-Analysis Based on 30 Publications. Asian Pac J Cancer Prev. 2015; 16:4457-4463.

22. Fang DH, Fan CH, Ji Q, Qi BX, Li J, Wang L. Differential effects of paraoxonase 1 (PON1) polymorphisms on cancer risk: evidence from 25 published studies. Mol Biol Rep. 2012; 39:6801-6809.

23. Kim HI, Cheong JH, Song KJ, An JY, Hyung WJ, Noh SH, Kim CB. Staging of adenocarcinoma of the esophagogastric junction: comparison of AJCC 6th and 7th gastric and 7th esophageal staging systems. Ann Surg Oncol. 2013; 20:2713-2720.

24. Colquhoun A, Arnold M, Ferlay J, Goodman KJ, Forman D, Soerjomataram I. Global patterns of cardia and non-cardia gastric cancer incidence in 2012. Gut. 2015; 64:1881-1888.

25. Gonenc A, Erten D, Aslan S, Akinci M, Simsek B, Torun M. Lipid peroxidation and antioxidant status in blood and tissue of malignant breast tumor and benign breast disease. Cell Biol Int. 2006; 30:376-380.

26. Li W, Tse LA, Au JS, Yu KS, Wang F, Yu IT. Prognostic value of alcohol consumption and some other dietary habits for survival in a cohort of Chinese men with lung cancer. Chin J Cancer. 2017; 36:21.

27. Cerliani MB, Pavicic W, Gili JA, Klein G, Saba S, Richard S. Cigarette smoking, dietary habits and genetic polymorphisms in GSTT1, GSTM1 and CYP1A1 metabolic genes: A case-control study in oncohematological diseases. World J Clin Oncol. 2016; 7:395-405.

28. Li YL, Feng F, Yan J, Chen LL, Li XL, Liu WH, Yang YF. Association between cured meat consumption and risk of colorectal cancer in people with different dietary habits and lifestyles. [Article in Chinese]. Zhonghua liu xing bing xue za zhi. 2016; 37:1006-1011.

29. Wielsoe M, Gudmundsdottir S, Bonefeld-Jorgensen EC. Reproductive history and dietary habits and breast cancer risk in Greenlandic Inuit: a case control study. Public Health. 2016; 137:50-58.

30. Azeem K, Horakova D, Tomaskova H, Prochazka V, Shonova O, Martinek A, Kysely Z, Janout V, Kollarova H. Evaluation of Dietary Habits in the Study of Pancreatic Cancer. Klin Onkol. 2016; 29:196-203.

31. Eroglu M, Yilmaz N, Yalcinkaya S, Ay N, Aydin O, Sezer C. Enhanced HDL-cholesterol-associated anti-oxidant PON-1 activity in prostate cancer patients. Kaohsiung J Med Sci. 2013; 29:368-373.

32. Delimaris I, Faviou E, Antonakos G, Stathopoulou E, Zachari A, Dionyssiou-Asteriou A. Oxidized LDL, serum oxidizability and serum lipid levels in patients with breast or ovarian cancer. Clin Biochem. 2007; 40:1129-1134.

33. Kahraman FU, Torun E, Osmanoglu NK, Oruclu S, Ozer OF. Serum oxidative stress parameters and paraoxonase- 1 in children and adolescents exposed to passive smoking. Pediatr Int. 2017; 59:68-73.

34. Eom SY, Yim DH, Lee CH, Choe KH, An JY, Lee KY, Kim YD, Kim H. Interactions between paraoxonase 1 genetic polymorphisms and smoking and their effects on oxidative stress and lung cancer risk in a Korean population. Plos One. 2015; 10:e119100.

35. Wang H, Li L, Ding L, Zhang Z, Pu C. Association of genetic polymorphisms in the paraoxonase 1 gene with the risk and prognosis of non-small cell lung cancer in Chinese Han population. J Invest Med. 2012; 60:592-597.

36. Tang W, Chen S, Chen Y, Lin J, Lin J, Wang Y, Liu C, Kang M. Programmed death-1 polymorphisms is associated with risk of esophagogastric junction adenocarcinoma in the Chinese Han population: A case-control study involving 2,740 subjects. Oncotarget. 2017; 8:39198-39208. https:// doi.org/10.18632/oncotarget.17338. 